\title{
Utilization of Library Facilities by Pre-Service Science Teachers: Information Literacy and Scientific Literacy Perspectives
}

\section{Fen Bilgisi Ö̆̆retmen Adaylarının Kütüphane Hizmetlerinden Yararlanmaları: Bilgi Okuryazarlığı ve Bilimsel Okuryazarlık Bakış Açısı}

\author{
Kübra Ayık ${ }^{1}$, Zekai Ayık² ${ }^{2}$
}

${ }^{1}$ Harran Üniversitesi, Kalite Kordinatörlüğü, Sanlıurfa, Türkiye

${ }^{2}$ Araş. Gör., Harran Üniversitesi, Eğitim Fakültesi, Matematik ve Fen Bilimleri Eğitimi Bölümü, Şanlıurfa, Türkiye

ORCID: K.A. 0000-0002-6957-2758; Z.A. 0000000235626543

Corresponding author/Sorumlu yazar: Kübra Ayık,

Harran Üniversitesi, Kalite Koordinatörlüğü, Şanlıurfa, Türkiye

E-mail: kubra.ozyurt34@gmail.com

Submitted/Başvuru: 14.04.2021

Revision Requested/Revizyon Talebi: 04.05.2021 Last Revision Received/Son Revizyon: 05.05.202 Accepted/Kabul: 10.05.2021

Published Online/Online Yayın: 25.06.202

Citation/Atıf: Ayık, K. ve Ayık, Z. (2021).

Utilization of library facilities by pre-service science teachers: Information literacy and scientific literacy perspectives. Bilgi ve Belge Araştırmaları Dergisi, $15,59-71$.

http://doi.org/10.26650/bba.2021.15.03

\begin{abstract}
Many scholars in the field accept scientific literacy as a main component of science education. Scientific literacy is depicted as accessing and obtaining scientific information and knowing how to do science. Next, information literacy is seen as an indispensable competency for science students to be scientifically literate persons. Given the crucial role in information literacy, utilizing print and online information resources that academic libraries provide may help science students get reliable and up-to-date information pertaining to science and latest developments. As such, this study aims to investigate, how pre-service science teachers as science students use print and digital information resources in the context of scientific literacy competency and explore relationships between various usages of library facilities. The study adopts an explorative descriptive method to get data about the point of interest. 82 pre-service science teachers joined the study. Data was statistically analyzed. Results indicate the utilization of various physically and virtually accessible information resources are below expectations. The study proposes a collaboration between science educators and information scientists in creating enhancements in the use of information facilities those libraries provide. This collaboration may help science students to enhance information, literacy and scientific literacy competencies.
\end{abstract}

Keywords: Scientific literacy, Information literacy, Library use, Library facilities

ÖZ

Fen eğitimi alanındaki birçok bilim insanı, bilimsel okuryazarlığı fen eğitiminin ana bileşeni olarak kabul etmektedir. Bilimsel okuryazarlık, genel olarak bilimsel bilgiye ulaşmak ve elde etmek ve bilimin nasıl yapıldığını bilmek olarak tanımlanmaktadı. Ayrıca, bilgi okuryazarlı̆̆ fen öğrencilerinin fen okuryazarı bireyler olmaları için vazgeçilmez bir yetkinlik olarak görülmektedir. Bilgi okuryazarlığındaki bu önemli rol göz önüne alındığında, akademik kütüphanelerin sağladığı basılı ve çevrimiçi bilgi kaynaklarından yararlanmak, bilim öğrencilerinin bilim ve en son gelişmelerle ilgili güvenilir ve güncel bilgiler edinmelerine yardımcı olabilir. Bu nedenle, bu çalışma fen bilgisi öğretmen adaylarının fen bilgisi ögrencileri olarak basılı ve dijital bilgi kaynaklarını bilimsel okuryazarlık yeterliliği bağlamında nasıl kullandıklarını araştırmayı ve kütüphane olanaklarının çeşitli kullanımları arasındaki ilişkileri incelemeyi amaçlamaktadır. Çalı̧̧ma, ilgilenilen araştırma konusu hakkında veri elde etmek için keşfedici ve betimsel bir yöntem benimser. Araștırmaya 82 fen bilgisi öğretmeni adayı katılııștır. Veriler istatistiksel olarak analiz edilmiştir. Sonuçlar, çeşitli fiziksel ve elektronik olarak erişilebilir bilgi kaynaklarının kullanımının beklentilerin alında olduğunu göstermektedir. Çalışma, kütüphanelerin sağladığı bilgi olanaklarının kullanımında iyileștirmeler yaratmak için bilim eğitimcileri ve bilgi bilimcileri arasında bir işbirliği önermektedir. Bu işbirliği, fen bilgisi öğrencilerinin ve öğretmen adaylarının bilgi, okuryazarlık ve bilimsel okuryazarlık yeterliliklerini geliştirmelerine yardımcı olabilir. Anahtar kelimeler: Bilimsel okuryazarlık, Bilgi okuryazarlı̆̆ı, Kütüphane kullanımı, Kütüphane olanakları 


\section{INTRODUCTION}

Many scholars in the field of science education (Allchin, 2013, 2017; Lederman, 2007) proposed that the ultimate aim of science education is to educate persons who are scientifically literate. Scientific literacy has been an attractive topic for many studies for decades. McDonald and Abd-El-Khalick (2017) posit that being scientifically literate necessitates having the ability to (1) "apply and reason scientifically" (2) "command the discourse of science", and (3) "understand the historical and epistemological significance of the learned concepts". Besides, Miller (1983) claims that scientific literacy has three roots. First of them is learning the scientific knowledge in different epistemological status (facts, theories, hypotheses, laws etc.), second is understanding and doing basic science processes where students should learn how science is practiced and done. Finally, parallel to Allchin's (2017) functional scientific literacy idea, adopting a positive attitude toward scientific thinking and using scientific reasoning in daily life are seen as basic requirements of scientific literacy.

The term "scientific literacy" was coined in the late 1950s along with the book Hurd (1958) which is entitled Science Literacy: Its Meaning for American Schools. Miller (1983, p. 31) defined it as consisting of three dimensions: (a) "an understanding of the norms and methods of science" (i.e., the nature of science); (b) "an understanding of key scientific terms and concepts" (i.e., science content knowledge); and (c) "an awareness and understanding of the impact of science and technology on society". This could be interpreted as understanding how science works and progresses, how its nature is, and understanding scientific knowledge and mutual interaction between science and society.

Laugksch (2000, p. 74) emphasizes that scientific literacy is a term which is interpreted up to various factors. Those factors include "interest groups, conceptions of scientific literacy, the nature of the concept scientific literacy of which scientific discipline differs, why is scientific literacy important, and ways of measuring scientific literacy". Interest groups are "science education community", "social scientists and public opinion researchers", "sociologists of science", "science educators employing a sociological approach to scientific literacy", and "the informal and non-formal science education community, and those involved in general science communication". According to him the science education group deals with scientific literacy in terms of issues such as "the goals of science education", "how personal skills, attitudes, and values implied by the goals are successfully incorporated into the science curriculum, and effectively taught by teachers"; "the quality and nature of resources required to achieve these goals efficiently", and "appropriate measures of assessment to ascertain to what extent the goals for science education have been met".

Pollak (1993) posits that as scientific literacy is an aim of science education, scientific literacy also needs science through education by which students can "broaden" and "strengthen" 
their knowledge. He emphasizes that one of the requirements of scientific literacy is to "keep up with the knowledge explosion" because scientific knowledge grows day by day. Boulding and Senesh (2019) argue that scientific literacy involves finding and using science knowledge. Norris and Phillips (2003) describe science literacy as a concept which foregrounds reading and writing as fundamental. They argue that "... science literacy comprises both the concepts, skills, understandings, and values generalizable to all reading, and knowledge of the substantive content of science" (Norris \& Phillips, 2003, p. s. 235).

Klucevsek (2017) asserts that, "one of the most fundamental and continuous parts of the scientific process is information literacy" which is "essential to continue to review the literature and search for new conversations while asking questions, designing experiments, analyzing data, and performing research". Klucevsek adds that one of the requirements of scientific literacy is achieving a wide range of knowledge and abilities true to the profession. In this context, it is noticed that information literacy plays a crucial role in succeeding in requirements of scientific literacy particularly in respect of obtaining general and disciplinary information. Information literacy is conceptualized by Doyle (1992) as "the ability to evaluate and use information from a variety of resources". Limberg, Sundin, and Talja (2012) state that information literacy is generally described as "the ability to search for, select, critically evaluate and use information for solving problems in various contexts". In its most conventional meaning, the term information in the information literacy context refers to (primarily textual) information sources published in print or digital form. Literacy is here not simply the skill to read and write, since people also need to be able to "understand, interpret and assess texts, to evaluate statements", and to be able to "take a standpoint when faced with flows of contradictory messages via various media and different types of sources".

What is more, Bruce (2003) focuses on the relation between information literacy and education by proposing "information literacy as a catalyst for educational change" and "information literacy as a prerequisite for lifelong learning". In this respect, Špiranec and Banek Zorica (2010) point out the strong relation between learning and information literacy by stating that academic success and the effectiveness of learning depends on competencies in accessing, evaluating, synthesizing, communicating and ethically using information" This idea is based on the view that education is not a direct transmission of facts, information or knowledge but "a process that involves creation, reflection and critical awareness". Therefore, as the core aspect of information literacy, and as the main connection with education, for a student, current understanding of education requires being able to "meaningfully interact with a wealth of information".

Leaning (2017) puts forth that information literacy is effective in helping students in contemporary and digital age to improve "earning potential" and preparing them "for a working life full of change". Hence information literacy may help persons be competitive 
in using and benefitting information which is vast and pretty accessible in this digital age. Pinto, Cordon, and Gómez Díaz (2010) notice that: "any graduate who wants to compete in the new knowledge economy will need to learn how to find, analyze, represent and evaluate and to use information."

Given that students may learn scientific authenticity (how science is done) from exploring and reading reports of scientific research and obtain the information from those resources, accessing information and being able to decode embedded meaning are an essential aspect of scientific literacy (Klucevsek, 2017; Phillips \& Norris, 2009). As mentioned before, scientific literacy involves understanding and comprehending ways of doing science. Klucevsek highlights that scientific publications depict and "mirror" procedural and organizational steps of processes in science. Libraries, particularly academic university libraries, are core elements in accessing resources of scientific information and publications (Breivik \& Ford, 1993; Swanson, 1979). Those resources both include print versions and electronic or digital formats. What is more, libraries are deemed as providers of reliable and authoritative information. This is especially important in the digital age where information is everywhere, and students are expected to find and use reliable information. Also, this is important where learning is considered the ability to navigate carefully among available information sources (Kalantzis \& Cope, 2020).

Many studies have demonstrated that libraries are systematic sources of scientific knowledge and its accumulation (Swanson, 1979). Libraries contain scientific textbooks from all disciplines of science. This means that scientific knowledge is laid in the textbooks as printed and electronic or digital sources. What is more, libraries offer access to reach many e-books and e-journals, and this facility enlarges the options to reach different sources of scientific knowledge. Libraries do not only offer printed or electronic sources of scientific knowledge that was contributed to disciplinary literature, but they also offer periodic sources of scientific knowledge by the means of scientific journals and magazines through which students can keep up their knowledge with current developments. Furthermore, most of the libraries facilitate studying environments. Students use them for studying a source from the library and may study for an exam and this factor could have a great effect on their academic achievement. Especially university libraries invest to develop their library facilities so that their students can benefit as much as possible. University libraries can be accepted as social environments where users gather scientific knowledge, share their knowledge, access various and different sources of scientific knowledge, and follow current trends in the science community. Because learning scientific concepts or knowledge, reach their different sources, and following the novel developments is accepted as one of the substantial elements of science education, it can be expected from pre-service science teachers to benefit from libraries at least as an effort to achieve their scientific literacy.

In this respect, even many researchers (Klucevsek, 2017; Krontiris-Litowitz, 2013; Shorish \& Reisner, 2016; Thompson \& Blankinship, 2015) suggest a collaboration between librarians 
and information scientists and science educators within science courses to promote information literacy skills and use of university libraries and help students access and use relevant literature of disciplinary scientific information and knowledge. In other words, as an integral part of scientific literacy, science process skills include "the ability to find resources, determine reliability, and understand content, are also basic professional skills" (Klucevsek, 2017) and libraries play a crucial role in access to reliable, systematic and various formats (print or electronic) of information. As such in the context of scientific literacy, the use of libraries may be an important factor to address significant aspects of scientific literacy. Therefore, we hypothesize that the use of libraries as information resources may develop science literacy skills and levels of science students.

Overall, those claims demonstrate that scientific literacy is a major component of science education. Lederman (2007) reports that the science teacher's understanding and competence within any particular area has reflected her or his pedagogical strategies. By knowing or doing any instructional ability, he or she will reflect the instructional aims. Therefore, it can be assumed that the scientific literacy level of a science teacher may affect her or his student's development of being scientifically literate. As such, regarding both individual learning success and their students in the future, pre-service science teachers should be educated as scientifically literate professionals. A review of literature shows that in science education research field there is a paucity of study to explore how future science teachers will use and utilize libraries to extend and promote their scientific literacy understanding and skills. In this respect, this study aims to explore how pre-service science teachers, who are expected to be scientifically literate, use and benefit from the university library. Library is considered as a facility where information is accessible at anytime and anywhere, not only by the building itself, but also by the digital and internet-based mediums.

\section{Research Questions, Method, Data Collection Tool and Data Analysis}

\subsection{Research Questions}

- $\quad$ For what purposes pre-service science teachers use both physical and on-line facilities of the library in the university they study?

- Are there any significant relationships between different user preferences in the use of library facilities?

\subsection{Method}

To address the research questions, this explorative and descriptive study adopts a survey method. For the first research question we employed descriptive frequency analysis and for the second question we employed descriptive crosstab analysis. In a quantitative approach, 
the methodology simply involves using a survey tool and obtains the participant's views and responses. Therefore, we adopted a questionnaire survey tool first. After taking the necessary and legal permissions, we contacted the second-year (sophomore) and third-year (junior) pre-service science teachers studying in the Faculty of Education, in the Harran University of Turkey. Participation was based on the volunteerism principle and the participants were informed about the procedure. We introduced the survey questionnaire and asserted that all data is kept anonymous and each participant may leave the research. 82 pre-service science teachers accepted to join the study voluntarily. In a certain date and time, all participants joined and responded to the questionnaire survey.

Given that the use of the library plays a crucial role in information literacy practices, the university library is also expected to provide a wide range of both print and electronic information resources. The university, where the participants study, has a central library which is in the central campus where the Faculty of Education is. The library has both print and electronic facilities. The library also provides internet and web-based online connections that enable the users to access the electronic and digital databases and periodicals. This facility allows users to access information resources from anywhere with an internet connection. What is more, the library has study halls where students can study individually or in groups.

\subsection{Data Collection Tool}

We decided to use a survey questionnaire instrument which is designed to reveal for what purposes and how frequently higher education students, or users use academic libraries. To succeed in this aim we have adopted the questionnaire previously developed by (Polat, 2005). The survey has likert-type response options. Those options are "very often", "often", "sometimes", "seldom", and "never". Those responses purport to figure out how frequently the user opt the directed and depicted facility of the library. Very often refers to more than 1-3 times in a week, often refers to 2-4 times in a month, sometimes refers to once in a month, seldom refers to 2-4 times in a term and finally never refers that the participant never benefits from the facilities of the library for the described aim. The tool has 13 likerttype questions and one open-ended question that aims to explore whether the participants have additional answers regarding the use of library facility or experience. The last item of the tool explores how frequently the users visit the library building. The instrument is presented in Appendix-1.

\subsection{Data Analysis}

The data is quantitatively analyzed in SPSS frequency analysis and Chi-square test of categorical responses. The main aim is to see how the specified usage field is preferred by participants totally rather than individual response analysis and envisage significant 
relationships between certain items. In other words, we efforted to see the popularity in use of determined library facilities and how frequently they are used. Data is demonstrated in frequency and percentages and Pearson-r values for relationships. Frequency demonstrates how many participants opted for a specific facility within Likert-type responses. Percentage demonstrates the ratio in use.

\section{Findings}

Each participant responded to the questionnaire in full participation. In a brief look, responses given to questionnaire surveys are presented in Table 1 and Table 2 below. Then we presented each individual item finding to discuss user preferences in each facility in detail.

Table 1. The frequency in benefitting from any library facility

\begin{tabular}{|l|c|c|c|c|c|c|c|c|c|c|}
\hline & \multicolumn{2}{|c|}{$\begin{array}{c}\text { Very Often } \\
(1-3 \text { times in a } \\
\text { week) }\end{array}$} & \multicolumn{2}{|c|}{$\begin{array}{c}\text { Often } \\
(\mathbf{2 - 4} \text { times in a } \\
\text { month) }\end{array}$} & \multicolumn{2}{c|}{$\begin{array}{c}\text { Sometimes } \\
\text { (Once in a } \\
\text { month) }\end{array}$} & \multicolumn{2}{|c|}{$\begin{array}{c}\text { Seldom } \\
(\mathbf{2 - 4} \text { times in a } \\
\text { term })\end{array}$} & \multicolumn{2}{c|}{ Never } \\
\hline Item & $\mathrm{f}$ & $\%$ & $\mathrm{f}$ & $\%$ & $\mathrm{f}$ & $\%$ & $\mathrm{f}$ & $\%$ & $\mathrm{f}$ & $\%$ \\
\hline $\begin{array}{l}\text { How often do you benefit } \\
\text { from any library facility? }\end{array}$ & 40 & 48,8 & 13 & 15,9 & 21 & 25,6 & 7 & 8,5 & 1 & 1,2 \\
\hline
\end{tabular}

The first item was asked to get data about how frequently the participant pre-service science teachers benefit from any library facility. As can be seen in the findings, $48,8 \%$ of participants visit very often, $15,9 \%$ of participants visit often, $25,6 \%$ of participants visit sometimes, $8,5 \%$ of participants visit seldom, and 2,9 \% of participants never visit library for this aim. Those findings indicate that except one participant, all participants benefit from any facility of the university library.

Chart 1. Demonstration of Frequency in Use of any Library Facilit

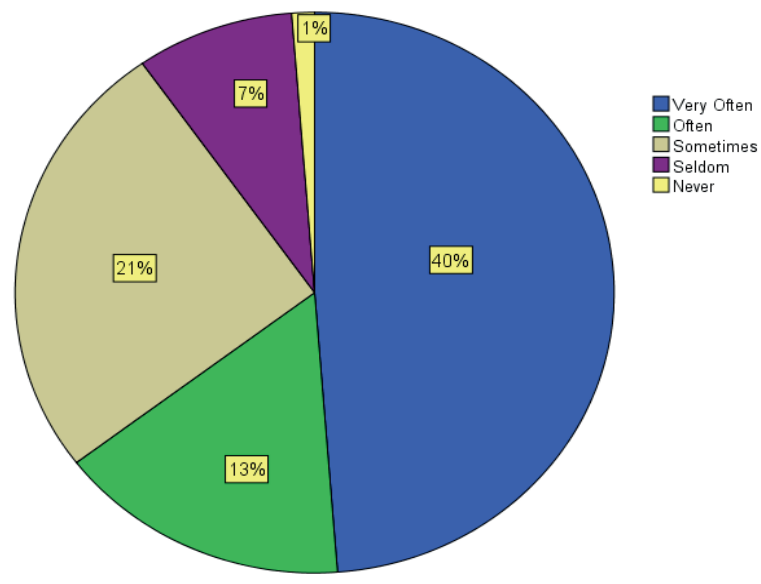


Table 2. Findings regarding use of library facilities

\begin{tabular}{|l|c|c|c|c|c|c|c|c|c|c|}
\hline & \multicolumn{2}{|c|}{$\begin{array}{c}\text { Very Often } \\
\text { (1-3 times in } \\
\text { a week) }\end{array}$} & \multicolumn{2}{|c|}{$\begin{array}{c}\text { Often } \\
(2-4 \text { times in } \\
\text { a month) }\end{array}$} & \multicolumn{2}{|c|}{$\begin{array}{c}\text { Sometimes } \\
\text { Once in a } \\
\text { month) }\end{array}$} & \multicolumn{2}{|c|}{$\begin{array}{c}\text { Seldom } \\
(2-4 \text { times in } \\
\text { a term) }\end{array}$} & \multicolumn{2}{|c|}{ Never } \\
\hline Item & $\mathrm{f}$ & $\%$ & $\mathrm{f}$ & $\%$ & $\mathrm{f}$ & $\%$ & $\mathrm{f}$ & $\%$ & $\mathrm{f}$ & $\%$ \\
\hline Borrowing books. & 11 & 13,4 & 19 & 23,2 & 33 & 40,2 & 8 & 9,8 & 11 & 13,4 \\
\hline $\begin{array}{l}\text { Getting printed resources } \\
\text { related to the courses I take. }\end{array}$ & 5 & 6,1 & 28 & 34,1 & 33 & 40,2 & 10 & 12,2 & 6 & 7,3 \\
\hline $\begin{array}{l}\text { To get the latest volumes of } \\
\text { the scientific journals in my } \\
\text { study field. }\end{array}$ & 2 & 2,4 & 6 & 7,3 & 17 & 20,7 & 23 & 28,0 & 34 & 41,5 \\
\hline $\begin{array}{l}\text { To access reference resources } \\
\text { such as dictionaries or } \\
\text { encyclopedias }\end{array}$ & 3 & 3,7 & 12 & 14,6 & 32 & 39,0 & 23 & 28,0 & 12 & 14,6 \\
\hline $\begin{array}{l}\text { Use the online databases to } \\
\text { access electronic journals and } \\
\text { books. }\end{array}$ & 2 & 2,4 & 9 & 11,0 & 26 & 31,7 & 16 & 19,5 & 29 & 35,4 \\
\hline $\begin{array}{l}\text { Studying in the library study } \\
\text { halls. }\end{array}$ & 32 & 39,0 & 24 & 29,3 & 22 & 26,8 & 3 & 3,7 & 1 & 1,2 \\
\hline Photocopying. & 6 & 7,3 & 3 & 3,7 & 10 & 12,2 & 8 & 9,8 & 55 & 67,1 \\
\hline
\end{tabular}

The findings show that more than half of students visit the library in intending to borrow books. The types of books that are implied here "in general" may involve novels etc. All participants seem to visit at least once for this category. To borrow any kind of printed book, $13,4 \%$ of participants visit the library very often, $23,2 \%$ often, $40,2 \%$ sometimes, $9,8 \%$ seldom, and finally $13,4 \%$ responded never. It is remarkable that a considerable percent of the users do not borrow any books. The second item asks the participants to rate whether the reason to visit the library is to get printed books related to their discipline, such as general chemistry books, or books about pedagogy. To get printed books related to their discipline, $6,1 \%$ of participants visit the library very often, $34,1 \%$ of participants visit the library often $40,2 \%$ of participants visit the library sometimes, $12,2 \%$ of participants visit the library seldom, and 7,3\% of them never visit the library for this aim. Results show that slightly less than half of the participants visit the library for getting those kinds of printed books. As well-known, academic libraries also provide its users with periodical issues of scientific journals in print formats. Besides the printed books related to their discipline, users may also want to see those periodical resources including scientific information and current developments. Findings reveals that $2,4 \%$ of participants visit the library very often, 7,3 $\%$ of participants visit the library often, $20,7 \%$ of participants visit the library sometimes, $28,0 \%$ of participants visit the library seldom, and $41,5 \%$ of participants never visit the library for this aim. 
To access reference resources such as dictionaries or encyclopedias, 3,7 \% of participants visit the library very often, 14,6 of participants visit the library often, 39,0 \% of participants visit the library sometimes, $28,0 \%$ of participants visit the library seldom, and $14,6 \%$ of participants never visit the library for this aim. The next category is about the usage of the online databases to access electronic journals and books. This category involves both the scanned versions of printed resources and electronic resources the library provides. Therefore, it is not just implied visiting the physical library building itself, it also implied the use of internetbased facilities of the library which students may get access and benefit without being at the campus. We also give importance to this facility especially in the times of COVID-19 pandemic when physical interaction and shared physical materials are absent. Data show that $2,4 \%$ of participants visit the library very often, $11,0 \%$ of participants visit the library often, $31,7 \%$ of participants visit the library sometimes, $19,5 \%$ of participants visit the library seldom, and $35,4 \%$ of participants never visit the library for this aim. These findings are also remarkable and surprising since higher percentages in the use of electronic information resources (remote use) are expected due to Covid-19 pandemic.

As known libraries provide well-designed individual and group spaces for their users to study. Users may study both resources, their own resources and information resources belonging to the library. This item explores how frequently the participants visit the library building to study. The item does not ask whether they do individual and group studies. Results show that $39,0 \%$ of participants visit the library very often, $29,3 \%$ of participants visit the library often, $26,8 \%$ of participants visit the library sometimes, 3,7 \% of participants visit the library seldom, and 1,2 \% of participants never visit the library for this aim. The last item asks the participants how frequently they visit the library building for photocopying of course materials or notes. Findings reveals that $7,3 \%$ of participants visit the library very often, 3,7 $\%$ of participants visit the library often, $12,2 \%$ of participants visit the library sometimes, 9,8 $\%$ of participants visit the library seldom, and $67,1 \%$ of participants never visit the library for this aim. It is worth it to indicate that almost half of the participants never visit the library buildings for this reason.

Table 3 demonstrates whether the participants get help from a library professional when they struggle with finding any information resource. This help request may be face-to-face or online. We asked this question to 45 participants. Findings show that most of the participants sometimes ask for help. This fact is crucial because if the students cannot find the resource she or he probably quit searching and they do not have access to the resource. Enabling users' access to Information resources is a major duty of a librarian. Hence, to accomplish this duty, users should ask for help and thus, users not only get access to the resource they want, they also may learn how to scan the catalog and access other resources they may need in the future. 
Table 3. Frequency in asking aid to a librarian to find an information resource

\begin{tabular}{|c|c|c|c|c|c|c|c|c|c|c|}
\hline \multirow[b]{2}{*}{ Item } & \multicolumn{2}{|c|}{ Very Often } & \multicolumn{2}{|c|}{ Often } & \multicolumn{2}{|c|}{ Sometimes } & \multicolumn{2}{|c|}{ Seldom } & \multicolumn{2}{|c|}{ Never } \\
\hline & $\mathrm{f}$ & $\%$ & $\mathrm{f}$ & $\%$ & $\mathrm{f}$ & $\%$ & $\mathrm{~F}$ & $\%$ & $\mathrm{f}$ & $\%$ \\
\hline $\begin{array}{l}\text { To find an information resource I } \\
\text { ask for help from a librarian. }\end{array}$ & 4 & 11,8 & 8 & 23,4 & 13 & 38,2 & 6 & 17,6 & 3 & 8,8 \\
\hline
\end{tabular}

The study also aims to investigate the relationship between the use of certain library facilities. We studied on four types of relationships. Those relationships are considered to monitor relationships between user preferences and choices. We employed descriptive crosstab analysis to see the relation between the items that have categorical answers. The chi-square results are expected to reveal whether there exist the significant relationships between the items or not. The Pearson-r value was used for interpretation. We firstly look at the relationship between the frequency in the use of library facilities and the frequency in visiting the library for borrowing printed resources. The Pearson-r value is 006 . This finding shows that there is a significant relationship between those two items. We interpret this finding as the participants have a tendency to borrow printed information resources when they visit the library. Secondly, we look at the relationship frequency in visiting the library and following the latest volumes of the periodic journals related to any specific discipline. The Pearson-r value is 0,178 which implies that there is not a significant relationship between visiting the library and following discipline related periodic journals. Users do not tend to use the latest volumes of scientific journals when they visit the library or benefit any library facility. Thirdly we look at the relationship between using library facilities or following the latest volumes of the disciplinary scientific journals and the use of online electronic databases. The findings show that there is a strong relationship between those two items. This means that users tend to benefit online electronic databases instead of printed versions of the periodical scientific journals. Lastly, we intended to see the relationship between the frequency in visiting the library for studying and the frequency in using a printed book through the visit. The findings indicate that there is a strong relationship between these two occurrences. This means that users mostly use printed books in the library when they visit. Remember that visiting the library for studying is popular among the participants. This situation implies that students mostly benefit from the printed information resources rather than electronic information resources when they study in the library.

\section{DISCUSSION AND SUGGESTIONS}

\section{Discussion}

The perennial goal of science education is helping students to be scientifically literate persons (McDonald \& Abd-El-Khalick, 2017). Many studies on conceptualization of scientific literacy claim that obtaining and increasing scientific knowledge and following current 
progresses, developments and trends in the science community are considered as strong requirements of scientific literacy. Accessing scientific information and knowledge is one of the vital requirements of scientific literacy. Accessing information resources and use of proper information for specific goals merge with the concept of information literacy which is generally explored by information scientists. The concept of "literacy" has become an increasingly popular field of research, especially after the dominance of screen-based information media. Scientific literacy and information literacy is well intertwined and interrelated by Klucevsek (2017), who claims that information literacy skills are vital for scientific literacy. The focus of this study is on the information literacy skills of pre-service science teachers in the context of development in scientific literacy. Furthermore, one main intention here is to foreground the use of libraries as an important component of information literacy (Breivik \& Ford, 1993). Use in frequency and purpose of use of academic libraries by their users may be indicators of information literacy skill. As such, this study purports to explore how future's science teachers and science students of now, benefit from facilities of the university library and how they get access to scientific information.

The findings show that students visit physically or virtually for various reasons from borrowing novels to photocopying. The frequency of visiting libraries is roughly once a week in total. This frequency may seem less for many undergraduate university students. When we consider accessing any information resource, students mostly borrow general books including novels etc., and the findings indicate that usage of disciplinary specific resources is around thirty percent which corresponds to one third of participants using library facilities to get information pertinent to scientific literacy skills. Another crucial point is that the usage ratio of electronic and internetbased facilities is low, that is almost one in four students never use this facility and the remaining student do not use it often. This situation demonstrates that facilities of the university library are not effectively used by pre-service science teachers regarding information literacy skills. As previously highlighted, information literacy is viewed as a "catalyst" for learning (Bruce, 2003) and a basic requirement of scientific literacy. Furthermore, information literacy is a vital competency of citizens of digital age where access to enormous information resources are easy with digital devices and internet connections. As such, information literacy is also vital for citizens to find, select, ethically use the information from a vast array of easily accessible resources (Stordy, 2015).

\section{Suggestions}

The results of this study indicate that there should be an interdisciplinary collaboration between science educators and information scientists or librarians. The idea that librarians and science educators should collaborate to increase knowledge and awareness in library facilities and the reliable and periodic information resources the academic libraries provides. This may help increase the information literacy skills of science students. Accordingly, as hypothesized, a rise in science literacy levels of those students may be observed. 
Ethics Committee Approval: This study was approved by the Ethical Committee of the Harran University, Social and Human Sciences. (Date:09.02.2021, No: 2021/22).

Peer-review: Externally peer-reviewed.

Author Contributions: Conception/Design of Study- Z.A., K.A.; Data Acquisition- Z.A., K.A.; Data Analysis/ Interpretation- Z.A., K.A.; Drafting Manuscript- Z.A..; Critical Revision of Manuscript- Z.A., K.A.;Final Approval and Accountability- Z.A., K.A.

Conflict of Interest: The authors have no conflict of interest to declare.

Grant Support: The authors declared that this study has received no financial support.

Etik Komite Onayı: Bu çalışma için etik komite onayı Harran Üniversitesi, Sosyal ve Beşeri Bilimler Etik Kurulu'ndan alınmıştır (Tarih:09.02.2021, No: 2021/22).

Hakem Değerlendirmesi: Dış bağımsız.

Yazar Katkıları: Çalışma Konsepti/Tasarım- Z.A., K.A.; Veri Toplama- Z.A., K.A.; Veri Analizi/Yorumlama- Z.A., K.A.; Yazı Taslağı- Z.A..; İçeriğin Eleştirel İncelemesi- Z.A., K.A.; Son Onay ve Sorumluluk- Z.A., K.A.

Çıkar Çatışması: Yazarlar çıkar çatışması bildirmemiştir.

Finansal Destek: Yazarlar bu çalışma için finansal destek almadığını beyan etmiştir.

\section{References/Kaynakça}

Allchin, D. (2013). Teaching the nature of science. Perspectives and Resources. St. Paul, MN: SHiPS Education Press.

Allchin, D. (2017). Beyond the consensus view: Whole science. Canadian Journal of Science, Mathematics and Technology Education, 17(1), 18-26.

Boulding, K. E. ve Senesh, L. (2019). The optimum utilization of knowledge: Making knowledge serve human betterment: Routledge.

Breivik, P. S. ve Ford, B. J. (1993). Promoting learning in libraries through information literacy. American Libraries, 24(1), 98-102.

Bruce, C. (2003). Information literacy as a catalyst for educational change: A background paper. Paper presented at the International Information Literacy Conferences and Meetings.

Doyle, C. S. (1992). Outcome Measures for Information Literacy within the National Education Goals of 1990. Final Report to National Forum on Information Literacy. Summary of Findings. Erişim adresi: https:// files.eric.ed.gov/fulltext/ED351033.pdf

Hurd, P. D. (1958). Science literacy: Its meaning for American schools. Educational Leadership, 16(1), $13-16$.

Kalantzis, M. Ve Cope, B. (2020). After the COVID-19 crisis: Why higher education may (and perhaps should) never be the same. ACCESS: Contemporary Issues in Education, 40(1), 51-55.

Klucevsek, K. M. (2017). The intersection of information and science literacy. Communications in Information Literacy, 11(2), 354-365.

Krontiris-Litowitz, J. (2013). Using primary literature to teach science literacy to introductory biology students. Journal of Microbiology \& Biology Education, 14(1), 66-77. doi:10.1128/jmbe.v14i1.538

Laugksch, R. C. (2000). Scientific literacy: A conceptual overview. Science Education, 84(1), 71-94. 
Leaning, M. (2017). Media and information literacy: An integrated approach for the 21st century. Chandos Publishing.

Lederman, N. G. (2007). Nature of science: Past, present, and future. Handbook of Research on Science Education, 2, 831-879.

Limberg, L., Sundin, O., ve Talja, S. (2012). Three theoretical perspectives on information literacy. Human IT: Journal for Information Technology Studies as a Human Science, 11(2), 93-130.

McDonald, C. V. ve Abd-El-Khalick, F. (2017). Representations of nature of science in school science textbooks. İçinde (pp. 1-19).

Miller, D. (1983). The correlates of entrepreneurship in three types of firms. Management Science, 29(7), 770-791.

Norris, S. P. ve Phillips, L. M. (2003). How literacy in its fundamental sense is central to scientific literacy. Science Education, 87(2), 224-240.

Phillips, L. M. ve Norris, S. P. (2009). Bridging the gap between the language of science and the language of school science through the use of adapted primary literature. Research in Science Education, 39(3), 313-319.

Pinto, M., Cordon, J. A. ve Gómez Díaz, R. (2010). Thirty years of information literacy (1977-2007) A terminological, conceptual and statistical analysis. Journal of Librarianship and Information Science, 42(1), 3-19.

Polat, C. (2005). Üniversitelerde kütüphane merkezli bilgi okuryazarlığı programlarının gelişstirilmesi: Hacettepe Üniversitesi örneği (Yayımlanmamış doktora tezi). Hacettepe Üniversitesi, Ankara.

Pollak, V. L. (1993). Science education - I: The spirit of science. Journal of Science Education and Technology, 2(4), 513-519.

Shorish, Y. ve Reisner, B. A. (2016). Building data and information literacy in the undergraduate chemistry curriculum. Integrating Information Literacy into the Chemistry Curriculum (Vol. 1232, pp. 31-56) içinde. American Chemical Society.

Špiranec, S. ve Banek Zorica, M. (2010). Information literacy 2.0: Hype or discourse refinement? Journal of Documentation, 66(1), 140-153. doi:10.1108/00220411011016407

Stordy, P. (2015). Taxonomy of literacies. Journal of Documentation, 71(3), 456-476. doi:10.1108/JD-102013-0128

Swanson, D. R. (1979). Libraries and the growth of knowledge. The Library Quarterly, 49(1), 3-25.

Thompson, L. ve Blankinship, L. A. (2015). Teaching information literacy skills to sophomore-level biology majors. Journal of Microbiology \& Biology Education, 16(1), 29-33. doi:10.1128/jmbe.v16i1.818 
